\title{
International outlaws
}

\author{
Elies van Sliedregt \\ Centre for Criminal Justice Studies, School of Law, University of Leeds, Leeds LS2 9JT, United Kingdom \\ Email: e.vansliedregt@leeds.ac.uk.
}

\section{Introduction}

In 2008, Kevin Heller wrote in this Journal a piece entitled: 'What Happens to the Acquitted?'. In the article he discusses the fate of former defendants who have been acquitted by the International Criminal Tribunal for Rwanda (ICTR) and who, after having been on trial, sometimes for years, have no country to relocate to. They cannot leave Arusha and join their families, most of whom live in Western-Europe and Canada. ${ }^{2}$ These states refuse to grant them access; they are not recognized as refugees. States can lawfully do so on the basis of Article 1F(a) of the 1951 Refugee Convention, which stipulates that persons seeking refuge can be excluded from protection when there are 'serious reasons for considering' they committed war crimes, crimes against humanity or crimes against peace. According to the UN Refugees Agency (UNHCR), the 'serious reason for considering' threshold falls short of the criminal law standard of 'beyond reasonable doubt', which means that even when acquitted, they remain undeserving for protection under the Refugee Convention. ${ }^{3}$ Sending the acquitted persons back to Rwanda is not an option because they will face prosecution for related charges. Moreover, there are concerns that such trials will not meet fair trial standards. ${ }^{4}$ In the interim, the former ICTR accused remain in a safe house in Arusha, waiting for a country that is willing to accept them. The registrar of the Rwanda tribunal has endeavoured to relocate acquitted persons and those who have served their sentences. ${ }^{5}$ This is an uphill struggle. States cannot be forced to co-operate and resettling those who have been accused of genocide is low on the list of priorities.

Twelve years since Heller's article not much has changed. Nine acquitted persons still reside in the Arusha safe house. ${ }^{6}$ The longest-resident, André Ntagerura, has been in the safe house since his acquittal in 2004. Despite a binding Security Council Resolution in 2018 that calls 'upon all states to cooperate with and render all necessary assistance to the Mechanism, for increased efforts towards the relocation of acquitted persons and convicted persons who have completed serving

\footnotetext{
${ }^{1}$ K. J. Heller, 'What Happens to the Acquitted', (2008) 21 Leiden Journal of International Law 663-80.

${ }^{2}$ Ibid., at 663; see further J. van Wijk and B. Hola, 'Life after conviction at international criminal tribunals. An empirical overview', (2014) 12 Journal of International Criminal Justice 109-32.

${ }^{3}$ UNHCR, Background Note on Exclusion, 4 September 2003, available at www.refworld.org/docid/3f5857d24.html.

${ }^{4}$ After abolishment of the death penalty in 2007 and other reforms the European Court of Human Rights ruled in the case of Ahorugeze v. Sweden (27 October 2011, Nr. 37075/09) that extradition to Rwanda would not violate Art. 6 of its Convention. Yet, in 2017, the UK High Court, in Rwanda v. Nteziryayo and others, [2017] EWHC 1912 (Admin), refused extradition to Rwanda for fair trial rights concerns.

${ }^{5}$ See the most recent report of the president of the Mechanism of International Criminal Tribunals: Seventh annual report of the International Residual Mechanism for Criminal Tribunals, dated 1 August 2019, to the General Assembly and to the Security Council, pursuant to article 32 (1) of the statute of the Mechanism. A/74/267, S/2019/622, 1 August 2019, available at www. irmct.org/sites/default/files/documents/190801-seventh-annual-report-en.pdf.

${ }^{6}$ Ibid.
} 
their sentences ${ }^{77}$ not much has happened. Until the asymmetry or mismatch of standards between international criminal law and international refugee law ('serious reasons for considering' versus 'beyond reasonable doubt') has been fixed refugee exclusion is a perfectly lawful way to hamper the relocation and resettlement of acquitted and sentenced persons.

\section{Refugee exclusion}

The 1951 Refugee Convention embodies the commitment to assure that refugees exercise fundamental rights and freedoms. Yet it also allows, in Article 1F, for exclusion from refugee status for those who (allegedly) committed serious crimes. At the time when the Convention was drafted, the memory of the trials of major war criminals was still fresh; there was agreement amongst states that war criminals should not be protected. ${ }^{8}$ Article $1 \mathrm{~F}$ contains three exclusion clauses ${ }^{9}$ but the one that is applied most frequently, is Article $1 \mathrm{~F}(\mathrm{a})$. This clause deals with war crimes, crimes against humanity (this includes genocide), and crimes against peace.

The rationale of exclusion is threefold: (i) to maintain the integrity of the Refugee Convention by excluding those who are 'undeserving' of protection, (ii) to ensure that those who have committed grave crimes do not escape prosecution, and (iii) to protect the state of refuge from criminal refugees who pose a threat to national security. ${ }^{10}$ The third reason should, however, be treated with caution since the primary provision that deals with threats to national security is Article 33(2) Refugee Convention. ${ }^{11}$

The majority of exclusion orders are not issued against those who have been tried by international tribunals. Article $1 \mathrm{~F}$ is most often used against persons who have never been indicted and probably never will be. For instance, in the Netherlands, hundreds of asylum claimants, mainly from Afghanistan and Iraq, have been excluded on the basis of Article $1 \mathrm{~F}$ (a) but remain unprosecuted because Dutch courts lack jurisdiction or because prosecutors refrain from prosecution for policy reasons (cost, unreliable witnesses). ${ }^{12}$ A similar situation exists in other Western states. ${ }^{13}$ At the same time, a considerable number of excluded persons cannot be sent back to their country of origin. Human rights obligations of the state of refuge pose an obstacle to sending them back to their country of origin where they will face ill-treatment. ${ }^{14}$ Also, claimants or their governments,

${ }^{7}$ UN Sec Res. 2422 (2018), 27 June 2018.

${ }^{8}$ UNHCR Handbook on Procedures and Criteria for Determining Refugee Status under the 1951 Convention and the 1967 Protocol relating to the Status of Refugees, HCR/IP/4/Eng/REV.1 Reedited, Geneva, January 1992, para. 148, available at www. unhcr.org/4d93528a9.pdf.

${ }^{9}$ The provisions of this Convention shall not apply to any person with respect to whom there are serious reasons for considering that: (a) He has committed a crime against peace, a war crime, or a crime against humanity, as defined in the international instruments drawn up to make provision in respect of such crimes; (b) He has committed a serious non-political crime outside the country of refuge prior to his admission to that country as a refugee; (c) He has been guilty of acts contrary to the purposes and principles of the United Nations.'

${ }^{10}$ UNHCR Handbook on Procedures, supra note 8, para. 148.

${ }^{11} \mathrm{Y}$. Li, Exclusion from Protection as a Refugee. An Approach to a Harmonizing Interpretation in International Law (2017), at 51 .

${ }^{12}$ M. P. Bolhuis and J. van Wijk, 'Alleged War criminals in the Netherlands: Excluded from refugee protection, wanted by the prosecutor', (2015) 12 European Journal of Criminology, at 151.

${ }^{13}$ M. P. Bolhuis and J. van Wijk, 'Study on the Exchange of Information between European countries regarding persons excluded from refugee status in accordance with Article 1F Refugee Convention', 2015, at 14-22, available at evalueringsportalen.no/evaluering/information-between-european-countries-regarding-persons-excluded-from-refugee-statusin-accordance-with-article-1f-refugee-convention/Study\%20on\%20the $\% 20$ exchange $\% 20$ of $\% 20$ information $\% 20$ on $\% 201 \mathrm{~F} \% 20$ exclusi.pdf/@@inline.

${ }^{14}$ Soering $v$. United Kingdom (ECHR, 14038/88), 7 July 1989. 
refuse to co-operate with departure. ${ }^{15}$ They end up in a 'legal limbo' with no right to reside or work and rely on support of family and civil society. In the UK and Australia, refugee claimants who are deemed undesirable and unreturnable live in detention. ${ }^{16}$

The connection between refugee law and criminal law is problematic not just because of the mismatch of thresholds that trigger exclusion. Article $1 F(a)$ of the 1951 Refugee Convention ${ }^{17}$ refers to crimes defined in 'international instruments'. This reference enables the import of broad (interpretations of) concepts of criminal responsibility. The concept of joint criminal enterprise (JCE) - developed at the International Criminal Tribunal for the Former Yugoslavia (ICTY) - has been relied upon by The Netherlands and Canada to exclude whole categories of people from refugee protection. ${ }^{18}$ Membership of security forces or certain political parties associated with a criminal regime, even if involuntary or on the margins, is sufficient to withhold refugee protection. ${ }^{19}$ In more recent years there have been attempts to curb these concepts. In 2013, the Canadian Supreme Court in the leading case of Ezokola ${ }^{20}$ reversed the course of refugee exclusion law by insisting that mere membership was too broad a test and that exclusion requires the stricter test of a 'voluntary, knowing and significant contribution' to a crime. ${ }^{21}$ Guilt by association is an insufficient ground on which to deny international refugee protection. However, three years later in Al-Ani v. Canada (Al-Ani) ${ }^{22}$, Canada's Federal Court upheld an administrative decision denying refugee status on the basis of the claimant's role in a government alleged to have committed international crimes. The same kinds of underlying acts that were before the Supreme Court in Ezokola were assessed under a second, distinct part of Canada's refugee system: the inadmissibility framework. ${ }^{23}$ This ruling illustrates the overlapping nature of Canada's inadmissability and exclusion regimes, a situation which is criticized by refugee law experts since it results in broad discretionary power for government decision-makers. ${ }^{24}$

The fundamental problem with refugee exclusion is that it brings together two areas of law that are very different, not in the least as to their outcomes. Refugee exclusion is binary; you are either granted access or not. ${ }^{25}$ This does not match with the more nuanced outcomes of a criminal law process (e.g., lenient sentences because of a minor role, reliance on a defence such as duress etc.). To overcome these differences and anomalies refugee law experts have proposed the harmonizing of IRL and ICL. Jenny Bond proposed a framework of exclusion law decision-making based on international criminal law. ${ }^{26}$ Yao Li proposes a similar approach. ${ }^{27}$ In her view, the exclusion clause is a quasi-punitive provision and must therefore be interpreted with due regard

\footnotetext{
${ }^{15}$ Bolhuis and Van Wijk, supra note 13, 14-22; see also M. P. Bolhuis, H. Battjes and J. van Wijk, 'Undesirable but Unreturnable Migrants in the Netherlands', (2017) 36 Refugee Survey Quarterly 61-84.

${ }^{16}$ S. S. Juss, 'Detention and Delusion in Australia's Kafkaesque Refugee Law', (2017) 36 Refugee Survey Quarterly 158-63;

S. Singer, “Undesirable and Unreturnable” in the United Kingdom', (2017) 36 Refugee Status Quarterly, at 20-2.

${ }^{17}$ Supra note 3.

${ }^{18} \mathrm{~J}$. Rikhof, The criminal refugee: the treatment of asylum seekers with a criminal background in international and domestic law (2012), 210-75; J. Bond, 'Principled Exclusions: A Revised Approach to Art. 1(F)(A) of the Refugee Convention', Background Study for the Michigan Guidelines on International Refugee Protection, (2013) 35 Michigan Journal of International Law 15-78.

${ }^{19}$ J. Bond, 'Excluding Justice: The Dangerous Intersection between Refugee Claims, Criminal Law, and "Guilty" Asylum Seekers', (2012) 24 International Journal of Refugee Law 37-59.

${ }^{20}$ Ezokola v. Canada [2013] SCC 40, [2013] S.C.R. 678. Similar rulings were adopted by the Supreme Courts of the UK and New Zealand respectively, in the cases of $R v$. Secretary of State for the Home Department, [2010] UKSC 15; The AttorneyGeneral v. Tamil $X$ and the RSAA, [2010] NZSC 107.

${ }^{21}$ Ezokola, ibid., at 680 .

${ }^{22}$ Federal Court of Canada, Al-Ani v. Canada (Minister of Citizenship and Immigration), 2016 FC 30.

${ }^{23}$ Immigration and Refugee Protection Act S.C. 2001, c. 27, sec. 35.

${ }^{24}$ J. Bond, N. Benson and J. Porter, 'Guilt by Association: Ezokola's Unfinished Business in Canadian Refugee Law', 39 (2020) Refugee Survey Quarterly, 1-25, at 10.

${ }^{25} \mathrm{~J}$. Bond, supra note $18,39-42$.

${ }^{26} \mathrm{~J}$. Bond, supra note 18.

${ }^{27} \mathrm{Y}$. Li, supra note 11.
} 
to international criminal law. So far, refugee exclusion practice shows no signs of pivoting to an ICL premised harmonized approach.

\section{Complementarity evasion?}

It is only in recent decades that resort to refugee exclusion has become popular. Despite its Nuremberg-inspired inception, it took until the early 1990s for frequent application of the exclusion clauses. With the fight against impunity extending to national jurisdictions, states have endorsed the principle of universal jurisdiction, enabling prosecution or extradition for international crimes committed by non-nationals outside a state's territorial jurisdiction. ${ }^{28}$ Langer and Euson, in a study on universal jurisdiction, demonstrate that conflict-based migration has brought more opportunities to exercise universal jurisdiction. ${ }^{29}$ Domestic endeavours to end impunity have led to an increase in refugee exclusion. States have made immigration services and prosecutorial services work together in an attempt to bring to justice (alleged) war criminals who claim asylum. ${ }^{30}$ Yet, while exclusion files are sent through to prosecutorial services, prosecution rarely follows. ${ }^{31}$

While, from the outset, refugee exclusion was linked to extradition/prosecution, there is no explicit mention of either in Article $1 \mathrm{~F}$ Refugee Convention. ${ }^{32}$ At the time of drafting the Convention, there was no realistic prospect of a competent (international) authority prosecuting asylum seekers. ${ }^{33}$ Expulsion to a third state or deportation to the state of origin was accepted as the more likely outcome of exclusion with subsequent prosecution a matter of chance. ${ }^{34}$ Also, the underlying philosophy of exclusion shifted from not granting refugee status as comporting with extradition obligations, to complying with the Convention's obligation to grant protection to those who do meet the refugee definition. ${ }^{35}$ With exclusion being widely viewed as grounded in the 'no safe haven policy', deportation and expulsion have become acceptable alternatives to dealing with asylum seekers who may have committed war crimes, crimes against humanity or genocide.

The Canadian programme operates on the premise that prosecution is costly, and that other (immigration) measures should be preferred such as preventing people obtaining citizenship, revoking citizenship, and removal of individuals. ${ }^{36}$ The question arises how this sits with Canada's obligations under the Statute of the International Criminal Court. Premised on the principle of complementarity, the ICC requires that member states contribute to ending impunity by prosecuting perpetrators of international crimes. The preamble stipulates in paragraph 4 that 'the most serious crimes of concern to the international community as a whole must not go unpunished and that their effective prosecution must be ensured by taking measures at the national level

\footnotetext{
${ }^{28} \mathrm{~J}$. Bond, supra note 18 , at 21.

${ }^{29}$ M. Langer and M. Eason, 'The Quiet Expansion of Universal Jurisdiction', (2019) 30 European Journal of International Law at 796-9.

${ }^{30}$ Bolhuis and van Wijk, supra note 13. REDRESS and FIDH, Strategies for the Effective Investigation and Prosecution of Serious International Crimes: The Practice of Specialised War Crimes Units, December 2010, available at www.fidh.org/IMG/ pdf/The_Practice_of_Specialised_War_Crimes_Units_Dec_2010.pdf.

${ }^{31}$ J. Fitzpatrick, 'The Post-Exclusion Phase: Extradition, Prosecution, Expulsion', (2000) 12 International Journal of Refugee Law 272-92; Bolhuis and van Wijk, supra note 12; M. A. van der Vlugt and G. F. W. van Zadelhoff, 'Art. 1 Vluchtelingenverdrag en de vervolging van internationale misdrijven in Nederland', (2013) Strafblad 179-87. An early comparative study is S. Kapferer, 'Exclusions clauses in Europe: A comparative overview of state practice in France, Belgium and the United Kingdom', (2000) 12 International Journal of Refugee Law 91-132.

${ }^{32}$ S. Kapferer, 'Article 14(2) of the Universal Declaration of Human Rights and Exclusion from International refugee protection', (2008) 27 Refugee Survey Quarterly 53-75.

${ }^{33}$ Fitzpatrick, supra note 31 , at $279-80$.

${ }^{34}$ Ibid., at 274 .

${ }^{35}$ Kapferer, supra note 31 , at $70-7$.

${ }^{36}$ Canada Department of Justice, 'War Crimes and Crimes Against Humanity', 24 October 2016, at 4, available at www. justice.gc.ca/eng/cj-jp/wc-cdg/index.html.
} 
and by enhancing international cooperation'. Moreover, the Statute recalls that it is the duty of every State to exercise its criminal jurisdiction over those responsible for international crimes' (paragraph 6). It seems that the 'no safe haven-policy' dominant in the aftermath of the Second World War has shifted to an 'ending impunity-policy'. With the emergence of an international criminal justice system where there is increased cooperation between national and international jurisdictions and amongst national jurisdictions, either via universal jurisdiction-treaties or through ICC's complementarity regime, one could argue that there is no longer place for postexclusion deportation, at least not when $\operatorname{Art} .1 \mathrm{~F}(\mathrm{a})$ is applied. The reliance on immigration measures to deal with excluded persons seems out of step with this evolution and certainly with duties states have under aut dedere aut judicare principles (universal jurisdiction) and the ICC Statute. ${ }^{37}$

\section{Hostis humanis}

The concept of 'undeserving' (of protection), which underlies all three exclusion clauses, is prone to abuse and manipulation for political purposes. It is linked to criminal conduct via the meaning of 'committing' in Article $1 \mathrm{~F}$ and comes down to drawing the line between association with criminal conduct and criminal complicity. This line shifts. Juss, in a piece on refugee exclusion in Germany, UK, Australia, and Canada, notes that in the post-9/11 era, refugee exclusion increasingly moves towards a concept of 'unworthiness for asylum' ${ }^{38}$ Broad legislation that criminalizes de minimis action but for the purposes of exclusion is equated to 'committing', risks undermining the institution of refugeehood. A doctrinal study and case-analysis can go some way in pinning down the legal meaning of 'committing' in Article 1F. Beyond that a normative evaluation seems required to scrutinize the assumptions that underlie the link between deserving of punishment and undeserving of protection. This would require a study into the concepts and imagery around 'enemy of mankind' and the rationale of punishment (nature of crime) versus the role one plays.

The Refugee Convention was drawn up in a time where the line between victors and vanquished, between war criminals and genuine refugees, was easier to draw. More than 50 years later, this image has changed. The trials against 23-year old Drazen Erdemovic before the ICTY, and child soldier Dominique Ongwen before the ICC have nuanced the picture of war criminals as 'enemies of mankind'. The majority of modern day (alleged) war criminals, certainly those prosecuted and tried at the domestic level, occupy lower positions in a military apparatus or criminal organization. This has affected the law. Whilst international criminal law had a more Spartan outlook at the time of Nuremberg, it is now in line with most (Western) criminal justice systems that recognize human frailty, through a system of defences, such as duress. In looking into the concept of 'undeserving' and interpreting it in the light of the assumptions underlying it, we might need to rethink refugee exclusion.

This brings me to the concept of 'outlaw'. There are still spaces where persons are considered 'rightless'. Terrorism suspects in Guantanamo Bay who cannot be tried for lack of evidence but are detained indefinitely and - in the past - pirates on the high seas as hostis humani generis (enemy of mankind) were found to be beyond legal protection. On this issue, the work of Arendt on statelessness and non-citizenship is of interest. In her view the idea of inalienable 'rights of man' is merely an ideal when there is no government or state to enforce such rights. ${ }^{39}$

The exclusion clause of the Refugee Convention and the policy to end impunity of those who are considered hostis humanis, generates a growing group of unwanted and undesirable individuals. The enemy of mankind narrative that comes with ICL is reflected in debates around foreign fighters and their brides. These people are regarded as having forfeited their right of protection via

\footnotetext{
${ }^{37}$ See also N. P. Weiss, 'Somebody Else's Problem: How the United States and Canada Violate International Law and Fail to Ensure the Prosecution of War Criminals', (2012) 45 Case Western Reserve Journal of International Law, 579-609.

${ }^{38}$ S. S. Juss, 'Complicity, Exclusion and the "Unworthy” in Refugee Law', (2012) 31 Refugee Survey Quarterly 1-39.

${ }^{39} \mathrm{H}$. Arendt, The Origins of Totalitarianism (1966), 291-3.
} 
citizenship. The link with ICL via war crimes enables lawmakers and politicians to argue in favour of an international justice system outside the regular court system, preferably outside the country; in a jurisdictional bubble - a space beyond sovereignty. ${ }^{40}$

\section{Concluding observations}

Refugee exclusion is here to stay. Experts in refugee and migration studies like James Simeon predict that exclusion will become more important, given that the root cause of forced displacement in the world today is protracted armed conflict and terrorism. ${ }^{41}$ In recent years, states have relied on Article 1F to exclude suspected terrorists from refugee protection. Syrian refugees have been excluded in Denmark and the Netherlands for being associated with war crimes and terrorism. ${ }^{42}$

There is a fundamental disconnect between international refugee law and international criminal law and a need for rethinking the relationship. The disconnect leads to a number of undesirable consequences undermining both the system of refugee protection and the system of international criminal justice. It generates a group of international outlaws, undermining the Refugee Convention's humanitarian purpose. Moreover, it facilitates complementarity evasion. Lastly, coupled with the idea of hostis humanis, it feeds into a justifying narrative of extra-judicial treatment.

\footnotetext{
${ }^{40}$ E. van Sliedregt, 'International Criminal Justice: A Bubble About To Burst?', in E. Hoven and M. Kubiciel (eds.), Zukunftperspektiven des Strafrechts. Symposium zum 70. Geburtstag von Thomas Weigend (2020), 253-77.

${ }^{41}$ J. C. Simeon, 'Refugee Adjudication Under the UNHCR's Mandate and Statute and the Post-Exclusion Dilemma', (2017) 2 Cambridge Law Review 75-108.

${ }^{42}$ Bolhuis, Battjes and van Wijk,supra note 15 , at 68.
}

Cite this article: van Sliedregt E (2020). International outlaws. Leiden Journal of International Law 33, 535-540. https:// doi.org/10.1017/S0922156520000217 